\title{
Peningkatan Kadar Interleukin 10 Setelah Cedera Otak Berat akibat Trauma Berhubungan dengan Skor FOUR Rendah
}

\author{
${ }^{1}$ David Loing, ${ }^{2}$ Eko Prasetyo, ${ }^{2}$ Maxmillian Ch. Oley
}

\author{
${ }^{1}$ PPDS Ilmu Bedah Fakultas Kedokteran Universitas Sam Ratulangi Manado \\ ${ }^{2}$ Divisi Bedah Saraf Bagian Ilmu Bedah Universitas Sam Ratulangi/RSUP Prof. Dr. R. D. \\ Kandou Manado \\ Email: davidloing@gmail.com
}

\begin{abstract}
Serum level of interleukin 10 (IL-10) and the FOUR score have both been suggested as predictors for the outcomes after severe traumatic brain injury (TBI). Studies are limited, however, on how they are related to each other. This study was aimed to assess the relationship between serum level of IL-10 and the FOUR score in patients with severe TBI. This was an observational study with a cross sectional design. The study was conducted on 25 severe TBI patients with FOUR score of 0-14 consecutively admitted at the the Emergency Surgery Installation of Prof. Dr. R. D. Kandou Hospital. Classification of the hemorrhage location (extra-axial, intra-axial, both), hemisphere (midline/diffuse, dextral, sinistral), and area (frontal, parietal, temporal, occipital, multiple) was established by using CT scans. Venous blood sample for IL 10 was performed less than 24 hours after trauma. Binary logistic regression was used to model the relationship of interest, with covariates selected through stepwise forward selection. The results obtained 25 patients dominated by males (84\%), with median age 31 . Mean IL-10 was $107.3 \mathrm{pg} / \mathrm{ml}$ (SD $16.2 \mathrm{pg} / \mathrm{ml}$ ). Median FOUR score was 10, with fairly equal proportion in the category of high (FOUR score $0-7 ; 48 \%$ ) and moderate (FOUR score 8-14; 52\%) mortality risks. Final regression model included age and injury on temporal area (yes, no) as covariates for IL-10. Adjusting for these variables, the average patients had about 1.12 (95\% CI 1.01, 1.25) times higher odds for worse FOUR scores (0-7, high mortality risk) in each $\mathrm{pg} / \mathrm{ml}$ addition of serum IL-10. Conclusion: The finding indicates that increased IL-10 level is a potential alternative to the lower FOUR score for predicting worse outcome in patients with severe TBI.
\end{abstract}

Keywords: IL-10; FOUR score; TBI

\begin{abstract}
Abstrak: Interleukin 10 (IL-10) serum dan skor FOUR disarankan sebagai prediktor luaran setelah cedera otak akibat trauma (COT) berat namun penelitian mengenai hubungan keduanya masih terbatas. Penelitian ini bertujuan untuk menilai hubungan antara kadar IL-10 serum dan skor FOUR pada pasien dengan COT berat. Jenis penelitian ialah observasional dengan desain potong lintang. Penelitian dilaksanakan pada 25 pasien dengan COT berat dan skor FOUR 0-14 secara berurut masuk ke UGD Prof. Dr. R. D. Kandou. Klasifikasi lokasi perdarahan (ekstra-aksial, intraaksial, keduanya), hemisfer (garis tengah/difus, dekstra, sinistra), dan area (frontal, parietal, temporal, oksipital, multipel) ditetapkan dengan $C T$ scan. Sampel darah vena untuk pemeriksaan IL-10 diambil kurang dari 24 jam setelah trauma. Regresi logistik biner digunakan pada model untuk hubungan ketertarikan dan kovariat stepwise forward. Hasil penelitian mendapatkan 25 pasien didominasi oleh laki-laki (84\%), median usia 31 tahun. Rerata IL-10 107,3 pg/ml (SD 16,2 $\mathrm{pg} / \mathrm{ml}$ ). Median skor FOUR 10 dengan proporsi berimbang pada kategori tinggi (skor FOUR 0-7; $48 \%$ ) dan sedang (skor FOUR 8-14; 52\%) risiko mortalitas. Model regresi akhir termasuk usia dan cedera area temporal (ya, tidak) sebagai kovariat untuk IL-10. Rata-rata pasien memiliki sekitar 1,12 (95\% CI 1,01-1,25) kali peluang lebih tinggi untuk skor FOUR yang lebih buruk (0-7, risiko kematian tinggi) pada setiap peningkatan $1 \mathrm{pg} / \mathrm{ml}$ kadar IL-10 serum. Simpulan: Temuan ini menunjukkan peningkatan IL-10 sebagai alternatif potensial terhadap skor FOUR yang lebih rendah untuk memrediksi hasil yang lebih buruk pada pasien dengan COT berat.
\end{abstract}

Kata kunci: IL-10, skor FOUR, COT 
Cedera otak akibat trauma (COT) adalah cedera kompleks yang disebabkan oleh trauma mendadak pada otak atau oleh benda yang menusuk jaringan otak dengan spektrum gejala dan kecacatan yang luas. ${ }^{1}$ Di Inggris, setiap tahun sekitar 100.000 kunjungan pasien kerumah sakit berkaitan dengan trauma kepala; $20 \%$ diantaranya memerlukan rawat inap. Di Amerika, cedera jenis ini menyebabkan 290.000 penderita dibawa ke rumah sakit; 51.000 di antaranya meninggal, dan 80.000 dengan cacat permanen. ${ }^{2}$ Di Indonesia, proporsi bagian tubuh yang cedera dan melibatkan kepala, menurut Riskesdas 2007 sekitar 19,6\%. ${ }^{2}$ Sebagian besar penyebabnya ialah perdarahan intrakranial yang dapat menyebabkan kematian. $^{4}$

Skor Full Outline of UnResponsiveness (FOUR) ialah skala koma baru yang dikembangkan dengan mempertimbangkan keterbatasan GCS serta sangat berguna dalam ruangan perawatan Intensif. Skor FOUR dapat memberikan informasi yang jauh lebih akurat terutama pada pasien terintubasi. Pada awalnya skor FOUR digunakan sebagai penilaian pasien koma untuk menilai tingkat kesadaran serta di gunakan untuk memantau kemajuan dalam perawatan pasien cedera kepala berat. ${ }^{5}$

Sitokin merupakan mediator penting dari neuroinflamasi setelah COT, yang mengatur beragam fungsi seluler melalui sinyal autokrin dan parakrin untuk mempertahankan imunopatologi yang tidak terkontrol. ${ }^{1}$ Peningkatan sintesis dan pelepasan berbagai sitokin pro dan anti inflamasi ke dalam sistem saraf pusat (SSP) dan darah dikaitkan dengan COT berat. ${ }^{5}$

Interleukin 10 (IL-10) diproduksi dalam konsentrasi tinggi oleh mikroglia dan infiltrasi monosit/makrofag pada fase akut cedera. Reaktivitas astrosit yang dirangsang oleh sitokin, berkontribusi terhadap peningkatan neuroinflamasi dan perkembangan cedera sekunder setelah neurotrauma. IL-10 bersifat pleiotropik dengan sifat anti-inflamasi dan meningkat pada hari pertama setelah trauma. ${ }^{2}$

Meskipun trauma telah terbukti memengaruhi tingkat IL-10, hubungan tingkat keparahan dan mortalitas cedera dengan tanggapan IL-10 pada fase awal trauma kecelakaan masih perlu diselidiki. ${ }^{1}$ Penelitian ini bertujuan untuk membantu para klinisi mendapatkan hubungan tentang efek IL-10 dan skor FOUR pada pasien cedera kepala berat.

\section{METODE PENELITIAN}

Penelitian ini merupakan studi analitik observasional dengan desain potong lintang. Seluruh informasi yang dibutuhkan diambil sekaligus saat pengambilan data dan tidak dilakukan follow-up survey. Subjek penelitian ialah 25 orang penderita COT berat yang termasuk dalam kriteria inklusi yaitu onset trauma saat masuk IRDB <24 jam, usia 16-45 tahun, COT dengan GCS 3-8 atau skor FOUR 0-14 tanpa memandang apakah pasien membutuhkan operasi atau tidak, serta penderita dengan intubasi dan dirawat di ICU RSUP Prof. Dr. R. D. Kandou Manado. Kriteria ekslusi ialah cedera otak berat bukan karena trauma, penderita menolak atau tidak dapat menjalani pemeriksaan kadar IL-10, mendapat infus dengan sedatif, analgetik narkotik, atau obat blok neuromuskuler, memiliki cedera penyerta seperti fraktur tulang panjang, trauma tumpul atau tajam pada toraks atau abdomen.

Pengumpulan data mencakup diagnosis fisik dan pemeriksaan klinis, fasilitas radiologi khususnya $C T$ scan, serta sampel darah untuk pemeriksaan kadar IL-10 di Laboratorium Fakultas Kedokteran Universitas Sam Ratulangi Manado.

Analisis data secara deskriptif untuk melihat distribusi variabel-variabel penelitian dilakukan secara univariat maupun bivariat. Analisis bivariat hubungan kadar serum dan skor FOUR dilakukan secara visual melalui scatterplot dan boxplot, dan secara analitik menggunakan prosedur koefisien korelasi Spearman's Rank

\section{HASIL PENELITIAN}

Aktivitas pengumpulan dan pengolahan data berpusat pada Instalasi Rawat Darurat Bedah (IRDB) dan Ruang Rawat Intensif (ICU) RSUP Prof. Dr. R. D. 
Kandou Manado sejak Maret hingga Juni 2018 yang memenuhi kriteria inklusi.

Tabel 1 memperlihatkan bahwa subjek penelitian ini didominasi oleh jenis kelamin laki-laki $(\mathrm{n}=21 ; 84 \%)$ dengan median usia 31 tahun (IQR 21, 43) tahun, dan median skor FOUR 10 (IQR 4, 13). Pemeriksaan CT scan menunjukkan bahwa cedera kepala para subjek terutama berlokasi di sekitar epidural, subaraknoid, atau subdural $(n=15$; $60 \%$ ). Sepuluh orang lainnya (40\%) mengalami perdarahan dalam otak atau kombinasi ekstra-aksial dan intra-aksial. Sebagian pasien (48\%) mengalami cedera pada hemisfer dekstra. Pemeriksaan laboratorium memperlihatkan mean kadar IL-10 serum setinggi 107,3 pg/mL (SD 16,2 $\mathrm{pg} / \mathrm{mL}$ ). Tabel 1 juga mengindikasikan bahwa sekalipun pasien laki-laki yang ikut serta dalam penelitian mendominasi subyek penelitian tetapi karakteristiknya cukup berimbang dengan subyek perempuan. Kedua jenis kelamin hanya berbeda $(P<0,05)$ dalam hal hemisfer yang terlibat; 3 dari 4 pasien perempuan menderita cedera kepala di sekitar garis tengah oksipitalis sedangkan cedera pada subjek laki-laki lebih cenderung mengenai hemisfer dekstra $(\mathrm{n}=12 ; 57 \%)$. Perbedaan lain kedua jenis kelamin tampak pada area cedera. Jumlah penderita dengan cedera kepala dan perdarahan di daerah oksipitalis sama pada kedua jenis kelamin $(n=3)$, namun jumlah tersebut mewakili proporsi yang berbeda ( $75 \%$ pada perempuan vs $14 \%$ pada lakilaki) sehingga merupakan perbedaan yang cukup bermakna.

Tabel 1. Karakteristik subjek penelitian menurut jenis kelamin, dalam Mean $\pm \mathrm{SD}$, Median $(\mathrm{Q} 1$, Q3), ataupun n (\%)

\begin{tabular}{lcccc}
\hline Karakteristik & $\begin{array}{c}\text { Total } \\
\mathrm{N}=25\end{array}$ & $\begin{array}{c}\text { Perempuan } \\
\mathrm{n}=4\end{array}$ & $\begin{array}{c}\text { Laki-laki } \\
\mathrm{n}=21\end{array}$ & $\boldsymbol{P}^{\boldsymbol{a}}$ \\
\hline Usia, tahun & $31(21,43)$ & $35(24,45)$ & $31(19,41)$ & 0,457 \\
Lokasi perdarahan ${ }^{\mathrm{b}}$ & & & & \\
$\quad$ Ekstra-aksial & $15(60 \%)$ & $4(100 \%)$ & $11(52 \%)$ & 0,347 \\
Intra-aksial & $8(32 \%)$ & $0(0 \%)$ & $8(38 \%)$ & \\
Kombinasi & $2(8 \%)$ & $0(0 \%)$ & $2(10 \%)$ & \\
Hemisfer yang terlibat ${ }^{\mathrm{b}}$ & & & & \\
Garis tengah/difus & $6(24 \%)$ & $3(75 \%)$ & $3(14 \%)$ & 0,015 \\
Dekstra & $12(48 \%)$ & $0(0 \%)$ & $12(57 \%)$ & \\
Sinistra & $7(28 \%)$ & $1(25 \%)$ & $6(29 \%)$ & \\
Area cedera & & & & \\
Frontalis & $6(24 \%)$ & $0(0 \%)$ & $6(29 \%)$ & 0,540 \\
Temporalis & $11(44 \%)$ & $1(25 \%)$ & $10(48 \%)$ & 0,604 \\
Parietalis & $8(32 \%)$ & $1(25 \%)$ & $7(33 \%)$ & $>0,100$ \\
Oksipitalis & $6(24 \%)$ & $3(75 \%)$ & $3(14 \%)$ & 0,031 \\
Multipel & $7(28 \%)$ & $1(25 \%)$ & $6(29 \%)$ & $>0,100$ \\
$\quad$ IL-10, pg/ml & $107,3 \pm 16,2$ & $104,5 \pm 13,0$ & $107,9 \pm 17,0$ & 0,714 \\
Skor FOUR & $10(4,13)$ & $10(9,11)$ & $7(4,13)$ & 0,457 \\
\hline
\end{tabular}

SD standar deviasi; $\mathrm{Q}_{1}$ kuartil pertama; $\mathrm{Q}_{3}$ kuartil ketiga; ${ }^{\mathrm{a}}$ nilai $P$ perbandingan laki-laki vs perempuan: untuk variabel numerik menggunakan uji t bila distribusi variabel normal dan uji Mann-Whitney U bila sebaliknya; untuk variabel kategori menggunakan uji Fisher's exact. 'berdasarkan hasil CT scan

Gambar 1 memperlihatkan distribusi skor FOUR menurut karakteristik subjek penelitian. Skor FOUR dengan risiko mor- talitas tinggi tampaknya lebih cenderung mengenai pasien dengan usia relatif muda (median 29 tahun, IQR 21 hingga 35 
tahun). Median usia pasien dengan skor FOUR berisiko mortalitas menengah ialah 41 tahun (IQR 25 hingga 45 tahun). Dalam hal lokasi perdarahan, proporsi kedua kategori skor FOUR bertolak belakang pada perdarahan ekstra-aksial dan intraaksial: masing-masing $67 \%$ vs $54 \%$ dan $25 \%$ vs $38 \%$, untuk skor FOUR dengan risiko mortalitas tinggi vs menengah. Menyangkut distribusi menurut hemisfer serebrum yang terlibat dalam cedera, skor
FOUR 0-7 cenderung lebih tinggi proporsinya daripada skor $8-14$ bila pasien mengalami cedera kepala pada hemisfer dekstra (58\% vs 38\%). Distribusi skor FOUR juga terlihat bervariasi menurut area utama yang mengalami cedera. Perdarahan pada area temporalis, misalnya, sangat didominasi cedera kepala dengan skor FOUR berisiko mortalitas tinggi $(67 \%$ vs $23 \%$ untuk skor $0-7$ vs skor 8-14).
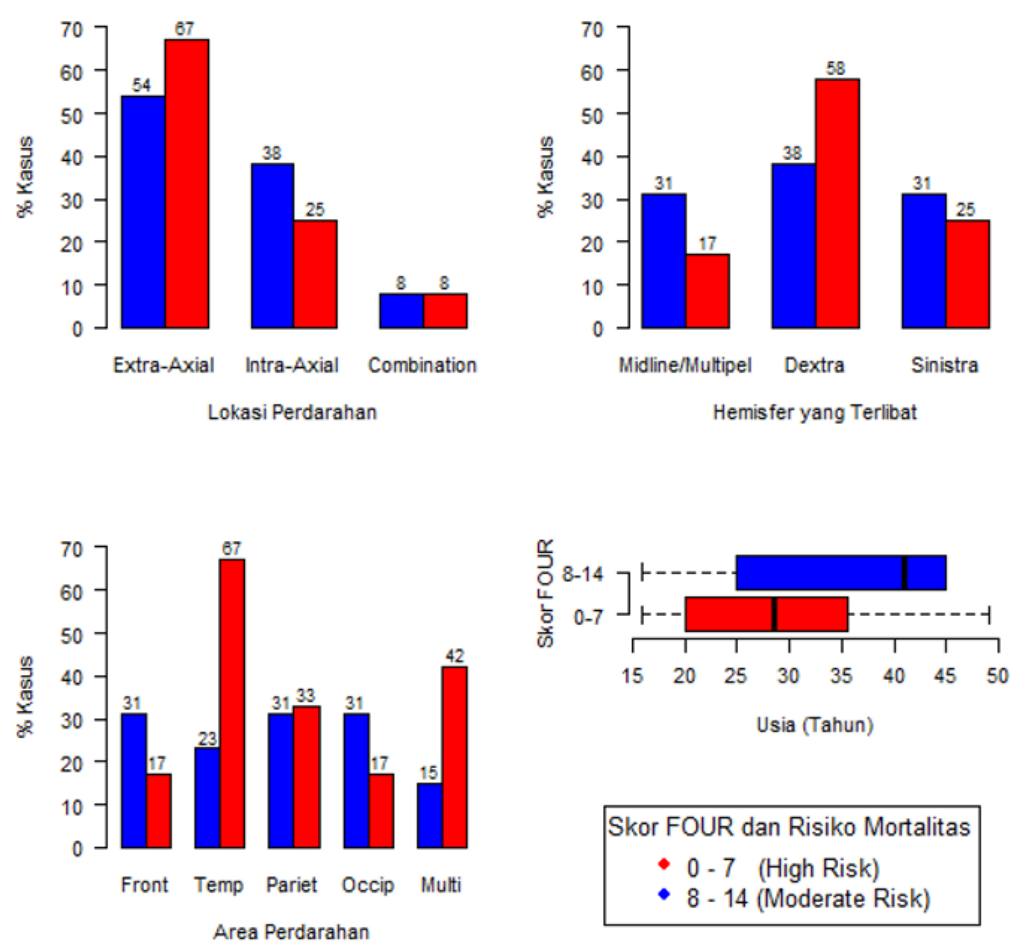

Gambar 1. Distribusi Skor FOUR menurut hasil CT scan dan usia pasien. Area perdarahan: Front $=$ frontalis, Temp $=$ temporalis, Pariet $=$ parietalis, Occip $=$ occipitalis, Multi $=$ multiple area

Gambar 2 memperlihatkan distribusi univariat dari kadar IL-10 serum yang tampak cukup normal $(P>0,05$ menurut uji Shapiro-Wilk), dengan mean $107,3 \mathrm{pg} / \mathrm{mL}$ (SD $16,2 \mathrm{pg} / \mathrm{mL}$ ). Berdasarkan hasil ini, penilaian IL-10 dalam analisis dilakukan tanpa transformasi skala pengukuran.

Gambar 3 menyajikan grafik bivariat antara kadar IL-10 serum dan skor FOUR, baik dalam skala asalnya (numerik) maupun setelah skor FOUR dijadikan variabel binary (skor 0-7 dan 8-14).

Hubungan kadar IL-10 serum dan skor FOUR pada scatterplot memang sedikit sulit dinilai secara visual. Penambahan kurva fit linear di atasnya membantu memperlihatkan tren hubungan negatif atau terbalik (peningkatan kadar IL-10 serum cenderung diikuti penurunan skor FOUR). Uji korelasi Spearman mengonfirmasi hubungan negatif tersebut $(P=-0,29)$, namun dengan nilai $P>0,05$. Boxplot memperlihatkan hubungan kadar IL-10 serum dengan skor FOUR dalam skala binary yaitu skor FOUR dengan risiko mortalitas tinggi lebih cenderung ditemukan pada pasien dengan kadar IL-10 serum relatif tinggi (Gambar 3). 


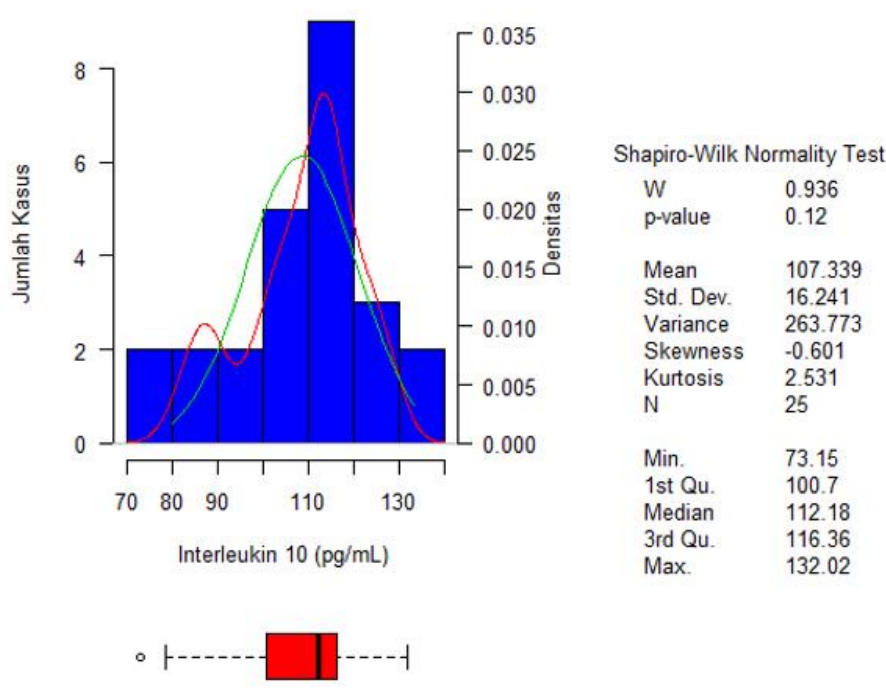

Gambar 2. Distribusi IL-10 pada subjek penelitian. Kurva merah pada histogram menunjukkan densitas, sedangkan kurva hijau ialah kurva distribusi normal

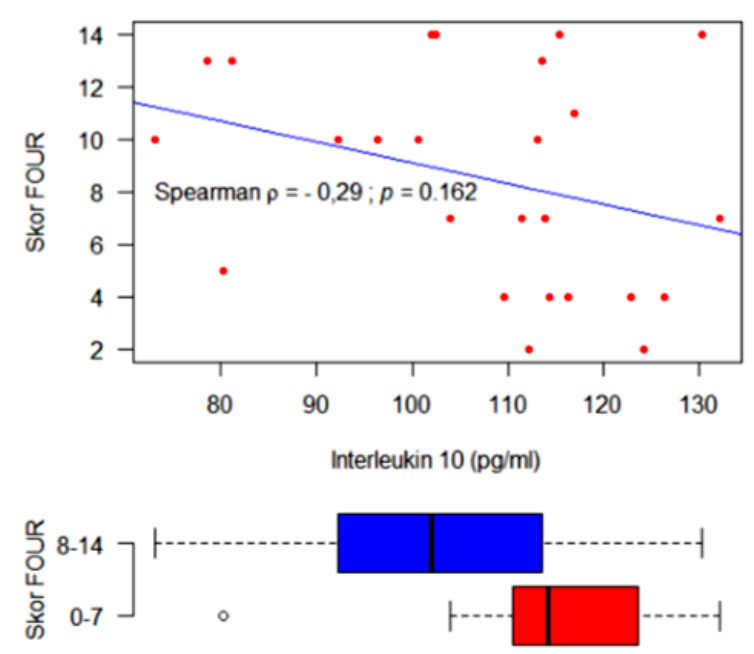

Gambar 3. Hubungan antara IL-10 dan skor FOUR

Tabel 2 menyajikan hasil pemodelan skor FOUR dalam bentuk kategori (risiko mortalitas tinggi vs menengah) dengan kadar IL-10 serum dan seluruh variabel penelitian lainnya sebagai prediktor. Kadar IL-10 serum sendiri tidak menunjukkan peran bermakna (hal yang telah nampak sebelumnya dalam Gambar 3). Sesuai hasil regresi logistik univariat skor FOUR (Tabel 2 ), cedera kepala yang mengenai lobus temporalis meningkatkan odds atau kemungkinan pasien mengalami keadaan dengan skor FOUR berisiko mortalitas tinggi sebesar hampir tujuh kali lipat (95\% CI 1,15-38,83), bila dibandingkan yang tanpa cedera lobus temporalis

Tabel 2 juga menunjukkan bahwa setelah pengaruh variabel-variabel perancu dikontrol, peran IL-10 serum menjadi bermakna. Lebih khusus lagi, model tersebut mengisyaratkan peningkatan odds 1,12 (95\% CI 1,01-1,25; $P=0,030)$ kali lebih besar atas skor FOUR 0-7 terhadap skor FOUR 8-14 di antara para pasien dalam setiap peningkatan $1 \mathrm{pg} / \mathrm{mL}$ kadar IL-10 serum setelah faktor usia dan adanya 
perdarahan pada area temporalis diperhitungkan. Selain IL-10, adanya cedera pada area temporalis memiliki OR 29,07 (95\% CI 1,56-542,16; $P=0,024)$. Sekalipun bermakna, interval OR yang cukup lebar ini mengingatkan keterbatasan jumlah subyek penelitian serta perlunya kehati-hatian dalam generalisasi hasil ini di luar subjek penelitian.

Tabel 2. Model regresi logistik Skor FOUR dengan kadar IL-10 serum sebagai faktor risiko utama

\begin{tabular}{lcccc}
\hline Variabel & \multicolumn{3}{c}{ Odds rasio (OR) skor FOUR 0-7 vs 8-14 } \\
& Model univariat & \multicolumn{2}{c}{ Model multivariat } \\
& OR 95\% (CI) & $P$ & OR 95\% (CI) & $P$ \\
\hline IL-10 & $1,06(1,00-1,13)$ & 0,067 & $1,12(1,01-1,25)$ & 0,030 \\
Laki-laki vs perempuan & $3,30(0,29-37,10)$ & 0,334 & & \\
Usia & $0,95(0,88-1,02)$ & 0,174 & $0,88(0,76-1,02)$ & 0,081 \\
Lokasi perdarahan $^{\mathrm{a}}$ & & & & \\
$\quad$ Ekstra-aksial & Referens & & & \\
Intra-aksial $_{\text {Kombinasi }}$ & $0,53(0,09-3,03)$ & 0,472 & & \\
Hemisfer yang terlibat ${ }^{\mathrm{a}}$ & $0,88(0,05-16,74)$ & 0,929 & & \\
$\quad$ Garis tengah/difus & & & & \\
$\quad$ Dekstra & Referens & & & \\
$\quad$ Sinistra & $2,80(0,36-21,73)$ & 0,325 & & \\
Area cedera & $1,50(0,16-14,42)$ & 0,725 & & \\
$\quad$ Frontalis & & & & \\
Temporalis & $0,45(0,07-3,07)$ & 0,415 & & \\
$\quad$ Parietalis & $6,67(1,15-38,83)$ & 0,035 & $29,07(1,56-542,16)$ & 0,024 \\
$\quad$ Oksipitalis & $1,13(0,21-6,05)$ & 0,891 & & \\
$\quad$ Multipel & $0,45(0,07-3,07)$ & 0,415 & & \\
\hline
\end{tabular}

CI, confidence interval; ${ }^{a}$ berdaarkan hasil CT scan

\section{BAHASAN}

Pada penelitian ini didapatkan sebanyak 25 pasien yang memenuhi kriteria inklusi dan diikut sertakan dalam penelitian. Hasil penelitian menunjukkan subjek penelitian didominasi oleh laki-laki $(\mathrm{n}=21$; $84 \%$ ) dengan median usia 31 tahun (IQR 21,43 tahun), dan berusia antara 16 hingga 45 tahun. Hal ini selaras dengan penelitian oleh Nair et $\mathrm{al}^{5}$ yang menyatakan bahwa umumnya pasien dengan cedera kepala berusia 20-50 tahun, jenis kelamin laki-laki lebih banyak dibandingkan perempuan, serta kecelakaan lalu lintas berkontribusi besar dalam cedera kepala $(78,3 \%) ; 82,6 \%$ nya ialah cedera kepala berat. Hal serupa juga dikemukakan oleh Satyanegara, ${ }^{1}$ yaitu distribusi kasus cedera kepala lebih banyak melibatkan kelompok usia produktif antara 15-44 tahun (dengan rerata usia sekitar 30 tahun) dan lebih didominasi oleh kaum laki-laki dibandingkan perempuan.

Hubungan antara kadar IL-10 serum dan kematian yang lebih tinggi akibat COT sebelumnya ditunjukkan oleh Bell et al ${ }^{6}$ pada anak dan dewasa dengan cedera tubuh termasuk beberapa pasien tanpa COT, namun temuan ini tidak dikonfirmasi lebih lanjut oleh Dziurdzik et $\mathrm{al}^{7}$ pada pasien dewasa dengan COT. Gomez et $\mathrm{al}^{8}$ mengemukakan bahwa usia merupakan salah satu prediktor kuat pada kematian karena cedera kepala akibat trauma. Pada penelitan ini didapatkan skor FOUR dengan risiko mortalitas tinggi tampaknya lebih cenderung mengenai pasien dengan usia relatif 
muda (median 29 tahun, IQR 21-35 tahun).

Sesuai hasil regresi logistik univariat skor FOUR, cedera kepala yang mengenai lobus temporalis meningkatkan odds atau kemungkinan pasien mengalami keadaan dengan skor FOUR berisiko mortalitas tinggi sebesar hampir tujuh kali lipat (95\% CI 1,15-38,83), bila dibandingkan mereka tanpa cedera lobus temporalis, Setiap peningkatan odds 1,12 (95\% CI 1,01-1,25; $P=0,030)$ kali peluang lebih tinggi untuk skor FOUR yang lebih buruk (0-7, risiko kematian tinggi). Dalam hal lokasi pendarahan, skor FOUR dengan mortalitas tinggi didapatkan pada perdarahan extraaxial dibandingkan intra-axial. Hal ini sesuai dengan penelitian yang dilakukan oleh Ostermann et $\mathrm{al}^{9}$ mengenai insiden abnormalitas CT pada initial CT scan kepala dan ekstra-aksial berisiko lebih tinggi untuk terjadinya kematian. Selain itu, area pendarahan menunjukkan bahwa skor FOUR dengan mortalitas tinggi didapatkan pada area temporalis. Hal ini disebabkan karena area temporal merupakan area yang sering terjadi trauma sesuai dengan mekanisme cedera jatuh serta kemungkinan besar mengalami hematoma epidural.

Hasil penelitian ini memperlihatkan kadar IL-10 serum terendah 73,15 pg/ml dan tertinggi $132,02 \mathrm{pg} / \mathrm{ml}$ dengan mean 107,3 pg/mL. Kadar IL-10 serum meningkat pada hari pertama setelah trauma. Salah satu studi menyatakan bahwa di otak, IL-10 meningkat dengan cepat selama 4 jam pertama setelah cedera dan tetap meningkat setidaknya 20 jam setelahnya. ${ }^{10}$ Pada penelitian lain telah dikonfirmasi bahwa ekspresi IL-10 pada COT yang parah meningkat lebih awal dan mencapai puncak dalam 2-8 jam cedera. ${ }^{11}$ Kadar IL-10 serum yang berbeda dikemukakan oleh Csuka et $\mathrm{al}^{12}$ yang mendapatkan rerata kadar IL-10 serum sebesar 5,4-23 pg/ml. Selain itu, pengambilan sampel IL-10 oleh Csuka et al dilakukan sampai hari ke-22, sedang-kan pada penelitian ini sampel diambil kurang dari 24 jam. Helmy et al $^{13}$ mendapatkan bahwa pada COT kadar IL-10 mencapai puncak di hari ke 5 dan 6 . Hal ini yang mungkin menyebabkan adanya perbedaan kadar IL-10 serum dalam kedua studi tersebut.

Interleukin-10 dianggap memiliki efek penghambatan potensial pada produksi beberapa mediator pro-inflamasi termasuk IL-1 $\beta$ dan TNF. Penghambatan IL-1 $\beta$ dan TNF merupakan fungsi yang paling penting, karena kedua sitokin ini diketahui memainkan peran sentral dalam inisiasi dan propagasi respons inflamasi. ${ }^{10}$

Hasil analisis univariat dan multivariat memperlihatkan tren negatif atau terbalik dimana peningkatan kadar IL-10 serum cenderung diikuti penurunan skor FOUR. Kadar IL-10 serum sendiri tidak menunjukkan peran bermakna. Usia dan lokasi pendarahan merupakan variabel yang menjadikan peran IL-10 menjadi bermakna. Cedera kepala yang mengenai lobus temporalis meningkatkan keadaan dengan skor FOUR berisiko mortalitas tinggi sebesar hampir tujuh kali lipat dibadingkan yang tanpa cedera lobus temporalis. Lebih khusus lagi, terjadi peningkatan 1,12 kali lebih besar atas skor FOUR 0-7 terhadap skor FOUR 8-14 di antara para pasien dalam setiap peningkatan $1 \mathrm{pg} / \mathrm{mL}$ kadar IL-10 serum. Penelitian yang dilakukan oleh Ferreira et al $^{11}$ mengemukakan bahwa peningkatan IL-10 dan IL-6 menunjukkan hasil yang tidak baik pada pasien dengan cedera kepala berat akibat trauma. Hal ini sesuai dengan penelitian ini yaitu peningkatan kadar serum IL-10 memiliki angka mortalitas tinggi. Mengenai peran anti-inflamasi IL-10, peningkatan IL-10 setelah COT berulang kali dikaitkan dengan outcome yang buruk dan kematian pada anak-anak dan orang dewasa setelah cedera otak berat akibat trauma. ${ }^{14}$

Pada penelitian ini dilakukan analisis terhadap 25 pasien dengan COT berat untuk menyelidiki efek interleukin 10 (IL10) terhadap skor FOUR. Hsil penelitian mendapatkan bahwa kadar IL-10 serum relatif tinggi cenderung pada pasien yang mempunyai skor FOUR dengan risiko mortalitas tinggi (0-7). Hasil pemeriksaan IL-10 dengan mean 107,3 pg/mL (SD 16,2 $\mathrm{pg} / \mathrm{mL}$ ) mengonfirmasi adanya hubungan negatif tersebut $(P=-0,29)$. 


\section{SIMPULAN}

Berdasarkan hasil penelitian ini dapat dibuktikan bahwa terdapat hubungan antara kadar IL-10 serum dengan skor FOUR. Peningkatan kadar IL-10 serum merupakan alternatif potensial untuk skor FOUR yang lebih rendah untuk memrediksi hasil yang lebih buruk pada pasien dengan COT berat.

\section{SARAN}

Disarankan untuk melakukan penelitian ke depan dengan jangka waktu lebih panjang dengan jumlah sampel yang lebih besar serta dilengkapi dengan follow-up survey yaitu kelompok kontrol dalam waktu 72 jam.

\section{DAFTAR PUSTAKA}

1. Satyanegara. Cedera kepala. Ilmu Bedah Saraf (5th ed). Jakarta: Gramedia, 2014; p. 31-44.

2. Sepahvand E, Jalali R. Glasgow coma scale versus full outline of unresponsiveness scale for prediction of outcomes in patients with traumatic brain injury in intensive care unit. Turk Neurosurg. 2015;18:9-13.

3. Laporan Nasional Riskesdas 2007. Available from: https://www.k4health.org/sites/ default/.../laporanNasional\%20Riskesd as\%202007

4. Jalali R, Rezaei MA. A comparison of the diagnostic power of the full outline of unresponsiveness scale and the glasgow coma scale in the discharge outcome prediction of patients with traumatic brain injury admitted to the intensive care unit. Crit Care Res Pract. 2014;2014:289803.

5. Nair SS, Surendran A, Prabhakar RB, Chisthi M. Comparison between FOUR score and GCS in assessing patients with traumatic head injury : a tertiary centre study. Int Surg J. 2017; 4(2):656-62.

6. Bell MJ, Kochanek PM, Doughty LA, Carcillo JA, Adelson PD, Clark RS, et al. Interleukin-6 and interleukin-10 in cerebrospinal fluid after severe traumatic brain injury in children. $\mathrm{J}$ Neurotrauma. 1997;14(7):451-7.

7. Dziurdzik P, Krawczyk L, Jalowiecki P, Kondera-Anasz Z, Menon L. Serum interleukin-10 in ICU patients with severe acute central nervous system injuries. Inflamm Res. 2004;53 (8):33843.

8. Gómez PA, Lobato RD, Boto GR, De la Lama A, González PJ, de la Cruz J. Age and outcome after severe head injury. Acta Neurochir (Wien). 2000; 142(4):373-80; discussion 380-1.

9. Ostermann RC, Joestl J, Tiefenboeck TM, Lang N, Platzere P, Hofbauer $M$. Risk factors predicting prognosis and outcome of elderly patients with isolated traumatic brain injury. J Orthop Surg. 2018; 13(1):277.

10. Garcia JM, Stillings SA, Leclerc JL, Philips H, Edwards NJ, Robicsek SA, et al. Role of interleukin-10 in acute brain injuries. Front Neurol. 2017; 8:244.

11. Ferreira LC, Regner A, Miotto KD, et al. Increased levels of interleukin-6, -8, and -10 are associated with fatal outcome following severe traumatic brain injury. Brain Inj J. 2014; 28(10): 11-6.

12. Csuka E, Morganti-Kossmann MC, Lenzlinger PM, Joller $H$, Trentz $\mathbf{O}$, Kossmann T. IL-10 levels in cerebrospinal fluid and serum of patients with severe traumatic brain injury: relationship to IL-6, TNF-alpha, TGF-beta1 and blood-brain barrier function. $\mathrm{J}$ Neuroimmunol. 1999;101(2):211-21.

13. HelmyA, GuilfoyleMR, CarpenterKLH, Pi ckard JD, Menon DK, Hutchinson PJ. Recombinant human interleukin-1 receptor antagonist in severe traumatic brain injury: a phase II randomized control trial. J Cereb Blood Flow Metab. 2014;34(5):845-51.

14. Thomas W, Morganti $K$. The role of markers of inflammation in traumatic brain injury. Front Neurol. 2013;4:1-18. 